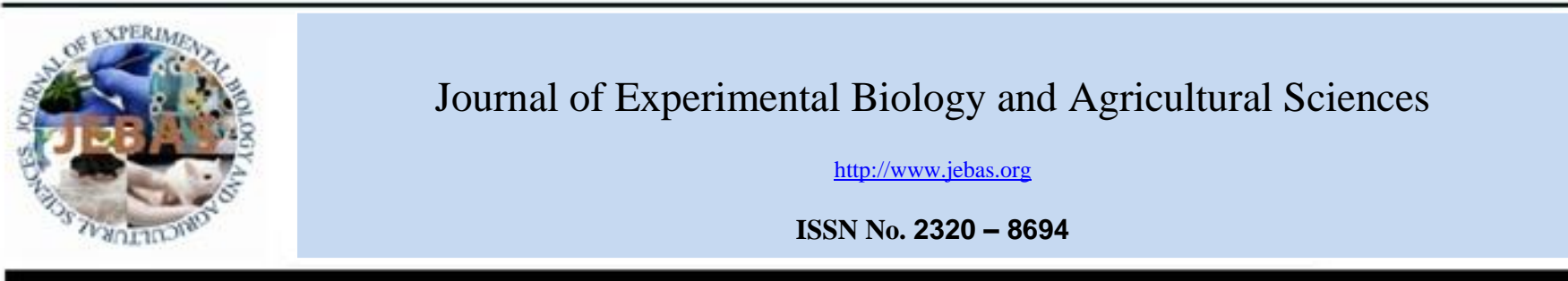

\title{
CROPPING SYSTEM ANALYSIS FOR AGRICULTURAL SUSTAINABILITY - PRODUCTIVITY, ECONOMY, ECOLOGY AND ENERGY USE EFFICIENCY
}

\section{Benukar Biswas}

Bidhan Chandra Krishi Viswavidyalaya, Mohanpur, Nadia, West Bengal, India 741252

Received - February 28, 2017; Revision - April 14, 2017; Accepted - June 05, 2017

Available Online - June 30, 2017

DOI: http://dx.doi.org/10.18006/2017.5(3).294.301

KEYWORDS
Cropping system
Economics
Energetics
Productivity

\section{ABSTRACT}

Field experiment was conducted during 2012-2013 and 2013-2014 at the Zonal Adaptive Research Station, Krishnagar, Nadia, West Bengal to find out alternative remunerative cropping systems in comparison to existing rice-rice and rice-wheat system through crop diversification and intensification in the Eastern Gangetic plain. Result of study revealed that the productivity of different cropping systems was in the order of jute - potato - rice $>$ rice - potato - rice $>$ rice - potato - sesame $>$ jute - rapeseed - rice $>$ jute - rice - rice $>$ rice - rapeseed - rice $>$ jute - wheat $>$ rice - rice $>$ rice - wheat. Further, results of study suggest that jute potato - rice, rice - potato - rice and rice - potato - sesame are suitable for large and medium farmers but these systems have higher energy productive at the cost of higher consumption resulting lower energy productivity. Moreover, for small and marginal farmers Jute - wheat and jute - rapeseed - rice cropping system considered suitable because of their moderate cost of production and net return.

* Corresponding author

E-mail: kripahi@yahoo.com(Benukar Biswas)

Peer review under responsibility of Journal of Experimental Biology and Agricultural Sciences.

Production and Hosting by Horizon Publisher India [HPI] (http://www.horizonpublisherindia.in/).

All rights reserved.
All the article published by Journal of Experimental Biology and Agricultural Sciences is licensed under a Creative Commons Attribution-NonCommercial 4.0 International License Based on a work at www.jebas.org.

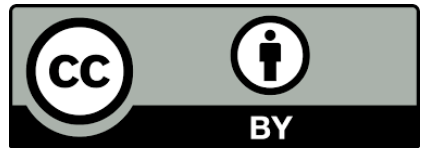




\section{INTRODUCTION}

India is divided in three tectonic divisions viz the Indo-Gangetic Plain (IGP), the Greater Himalayas, and the Decan Plateau. The IGP eco region is further divided into four major agro-climatic regions (ACRs) i.e. the Lower Gangetic Plain Region (ACR III), Middle Gangetic Plain Region (ACR IV), Upper Gangetic Plain Region (ACR V) and Trans Gangetic Plain Region (ACR VI). Most of the Lower Gangetic Plain is located in the state of West Bengal. Further, West Bengal has six agro-climatic sub regions : i) northern hilly, ii) Tarai-Teesta flood plain (ACR II), iii) Gangetic flood plain, iv) coastal flood plain (ACR III), v) Vindhya old flood plain and vi) undulating lateritic sub-region of Eastern Plateau Region (ACR VII) (SenGupta 2001). The Gangetic flood plain is the most fertile and biggest sub region $\left(19389 \mathrm{~km}^{2}\right)$. This zone experiences a sub-humid to humid and subtropical climate with more than 120 growing days, 1200-1600 mm rainfall and ustic moisture regime. It is primarily a traditional rice-growing area of the lower IGP. Three types of land, e.g., highland, medium and lowland, are found in this zone. Depending upon the land situation and rainfall, a number of crop sequences are followed by the farmers in the sub-region. In medium lands, farmers used to grow pulses such as grass pea, lentil, or Bengal gram after harvest of long duration photo-sensitive local rice in winter with low productivity and low return. However, after introduction of highyielding short duration rice and wheat in the 1970s and increasing irrigated area, dry season rice replaced those pulses in this area. Rice-rice and rice-wheat cropping systems became dominant system. In the IGP eco-region, several micro-level and macro-level studies of cropping systems have been conducted. Most of them were restricted to rice-wheat cropping systems (Sarkar, 1997; Timsina \& Connor, 2001; Bhandari et al., 2002). Mandal et al. (1981) reported some remunerative jute-based cropping system (jute-rice, jute-wheat, jute-potato, jute-mustard, jute-pulses, etc., under rainfed conditions and jute-rice-potato, jute-rice-wheat, juterice-mustard, jute-rice-pulses, etc. under irrigated conditions) in the jute growing tract of India. Kundu \& Samui (1998) evaluated the profitability of some rice-based cropping systems in the Nadia district of West Bengal. They found that rice-wheat-jute was most productive but had the lowest benefit: cost ratio, whereas ricemustard-sesame was least productive but had a high benefit: cost ratio. Kundu \& Samui (1998) reported rice-potato-rice-jute as the most productive and profitable cropping sequence among five cropping sequences tested (rice-potato-sesame, rice-wheatgroundnut, rice-mustard-rice-dhaincha, rice-mustard-rice). Based on exploratory diagnostic research in the form of a rapid rural appraisal conducted in potato growing districts of West Bengal, Roy et al. (1999) critically analysed the problems and prospects for intensification of potato production in rice-based cropping system particularly in rice-potato-rice and rice-potato-sesame systems. Mukhopadhyaya \& Ray (2000) reported potato-jute-rice as more productive system than three other systems (potato-moong-jute, potato-maize-rice and wheat-jute-rice) at Kalyani, West Bengal. In a comparative study of 16 cropping sequences under upland rainfed situation at Kalyani, Zaman \& Choudhuri (2001) reported that production potential, water use efficiency and net return were the highest in maize-wheat-moong, rice-safflower-moong, maizewheat-moong and blackgram-gram-moong sequence, respectively.

Most of the previous research concentrated either on a particular cropping system (e.g., rice-wheat system) or on the adaptability of specific crop-based cropping systems under different land situations. There is a need for a comprehensive evaluation of various cropping systems with regards to productivity, profitability, energy use etc to evaluate alternative cropping system through crop diversification and intensification.

\section{MATERIALS AND METHODS}

A field experiment was conducted during 2012-2013 and 20132014 at the Zonal Adaptive Research Station Farm, Krishnagar, Nadia, West Bengal, India $\left(88^{0} 31^{\prime} \mathrm{N}, 23^{0} 24^{\prime} \mathrm{E}\right), 15 \mathrm{~m}$ AMSL. The soil of the study area is wee-drained, sandy clay loam and very deep, with $53 \%$ sand, $25 \%$ silt and $22 \%$ clay in the surface layer $(0-15 \mathrm{~cm})$. Initial soil properties of the study area were $4.5 \mathrm{~g} \mathrm{~kg}^{-1}$ organic carbon (Walkley-Black), $0.44 \mathrm{~g} \mathrm{~kg}^{-1}$ total nitrogen (Kjeldahl), $34 \mathrm{~kg} \mathrm{ha}^{-1}$ available $\mathrm{P}$ (Bray-1), $144 \mathrm{~kg} \mathrm{ha}^{-1}$ available K (1 $\mathrm{NH}_{4}$-acetate), and a $\mathrm{pH}$ of 7.5 (1:2.5 soil : water). The experiment was conducted in RBD with nine cropping systems viz rice - rice (R-R), rice - wheat (R-W), rice - potato - rice (R-P-R), rice - potato - sesame (R-P-S), rice - rapeseed - rice (R-Re-R), jute - rice - rice (J-R-R), jute - wheat (J-W), jute - potato - rice (J-P-R) and jute - rapeseed - rice (J-Re-R), all the cropping system replicated thrice in $20 \mathrm{~m}^{2}$ plots. Various cultivars which were used in this study are: rice cv. MTU 7029 and jute cv. JRO 524 during rainy season; wheat cv. Sonalika, potato cv. Kufri Ashoka, rapeseed cv. B9 and rice cv. Kalinga 3 during winter; rice cv. Kalingo 3 and sesamum cv. Rama during summer were tested. Need-based eco safe protection measures were used during the complete study period. To compare performance of different cropping sequences, rice equivalent yield was calculated on price basis. Nutrient removal by crops and nutrient balance in soil under different cropping systems were evaluated.Eco friendly precaution measures were taken and in spites of this some of infestations or incidences of pests were observed and recorded as percentage of plant/tillers/grains infested/infected. Energy parameters were calculated as mentioned by Mittal et al. (1985). The analysis of variance method (Gomez \& Gomez, 1984) was followed to statistically analyse the various data. The significance of different sources of variation was tested by error mean square of Fisher Snedecor's 'F' test at probability level $(P=0.05)$.

\section{RESULTS AND DISCUSSION}

\subsection{Crop productivity:}

Rice produced higher grain yield than jute fiber yield during rainy season of 2012-2013; but in 2013-2014, rice only under ricepotato-rice and rice-potato-sesame cropping systems produced greater yield than in other cropping systems (Table 1). Jute under 
jute-potato-rice system also recorded higher fiber yield than in other jute - based cropping systems during the second year, perhaps because of high fertilizer applications to the potato crop. Both rice and jute gave the lowest yields during $2^{\text {nd }}$ year under rice-rapeseed-rice and jute-rapeseed-rice. Nutrient-exhaustive rapeseed tends to decline crop productivity (Biswas et al. 2006). Among winter crops, potato out-yielded others due higher yield potential of tuber and rapeseed produced the lowest yield irrespective of cropping systems. Potato played prominent role for the highest yield in jute-potato-rice sequence both in the first and second years. During summer, rice out-performed sesame in absolute yield during both years. Residual effect of jute was prominent on summer rice yield between the cropping sequences jute-potato-rice and rice-potato-rice. This may be beneficial effect of jute leaf shading, greater root biomass resulting better nutrient cycling, soil structure and root growth (Mandal et al., 1981).

Rice equivalent yields ranked as jute-potato-rice $>$ rice-potatorice > rice-potato-sesame > jute-rapeseed-rice > jute-rice-rice > rice-rapeseed-rice > jute-wheat $>$ rice-rice > rice-wheat. Cropping systems involving potato and jute were superior to those without, perhaps due to heavy manuring in potato and jute leaf shedding (Sadanandan \& Mahapatra, 1973a; Kundu 1989) as well as greater rhizodeposition and bioporosity of jute soils.

\subsection{Economics}

Triple cropping systems incurred considerably higher costs of cultivation than double cropping systems for both the years (Table 1). High cost of potato cultivation rendered triple cropping systems including potato the costliest. Production cost was low when wheat was grown under double cropping systems. Production cost was the highest in jute-potato-rice followed by rice-potato -rice and the lowest cultivation cost was with rice-wheat cropping system due to low input requirement in wheat. In spite of high cost of cultivation both gross and net returns were significantly higher in the cropping systems where potato is a component crop than all other double or triple cropping systems. The possible reason could be its quick and immediate sale in the markets due to high consumption in the society. The net returns estimated under different cropping systems ranked as jute-potato-rice > rice-potato-rice>rice-potato-sesame $>$ jute-rapeseed-rice > jute-rice-rice > jute-wheat > ricerapeseed-rice $>$ rice-rice $>$ rice-wheat. This clearly indicated the superiority of potato-inclusive cropping systems over others in term of gross and net returns. Jute-potato-rice system paid the highest returns of US $\$ 1748 \mathrm{ha}^{-1}$ and $1402 \mathrm{ha}^{-1}$ during $1^{\text {st }}$ and $2^{\text {nd }}$ year, respectively. High production cost related to high gross return, net return and return per dollar invested in jute-potato-rice, rice-potato-rice and rice-potato-sesame cropping systems, making them suitable for resource-rich farmers. Return per dollar invested was quite high in less common jute-wheat cropping system because farmers generally do care for the obvious parameters, such as gross and net returns. Considering diversity in framers income group, resource poor farmers can opt for jutewheat and jute-rapeseed- rice system for low investment requirement. With greater microcredit opportunity they can also opt for potato -inclusive cropping systems although potato is liable to unstable market price. Price rises from March (after harvesting of potato) to September (before harvesting of next potato). Biotic factor especially blight (either early or late or both) incidence sometimes dictate productivity of the current year and potato area of the subsequent year. Higher productivity and production results low price of the current year and lower potato area in the subsequent year and vice versa. Except rapeseed, production cost among winter crops was lower for wheat when it was included in the sequence due to its low labour requirement. Highest cost was recorded in J-P-R followed by R-P-R, R-P-S and J-R-R and the lowest one was obtained from R-W system. In spite of high cost involved in potato cultivation, net returns were consistently higher in cropping systems containing potato than any other double or triple cropping systems owing to very high yield of potato and its stable price. Net return from R-Rand R-W were the lowest. J-R-R and $\mathrm{J}-\mathrm{W}$ cropping systems also gave intermediate returns. Potato containing cropping systems also gave intermediate return. Potato containing cropping system also proved the best in terms of benefit per unit cost involved. J-W recorded high benefit cost ratio. Lowest BCR was recorded in R-R, R-Re-R, J-R-R and J-Re-R cropping system (Gangwar et al., 1986; Ghosh \& Dasgupta, 1995).

\subsection{Ecology}

Pressure due to pests was generally low for most of the crop seasons (Table 2). But, yellow stem borer (YSB, Tryporyza incertulas Walker) was the key pest in dry rice for both the years and in wet rice during $2^{\text {nd }}$ year, pesticides were applied to control it. Rapeseed also needed chemical protection against aphid (Lipaphis erysimi Kaltenbach). Yellow mite (Hemitasonemus latus Banks) in jute was at its highest in jute-potato-rice followed by jute-rapeseed-rice cropping systems albeit below economic threshold level (ETL). YSB incidence was highest at 60 days after transplanting of wet rice under rice-rice, rice-potato-rice and ricerapeseed-rice cropping systems during $2^{\text {nd }}$ year. Only rice gundhi bug (Leptocoriza varicornis Thunberg) exceeded ETL at 20 days after flowering of wet rice in rice-rice, rice-potato-rice and ricerapeseed-rice cropping systems during $2^{\text {nd }}$ year. Rice sheath blight (c.o.- Rhizoctonia solani AG 1A Kühn) exceeded ETL in wet rice under rice-rice, rice-potato-rice and rice-rapeseed-rice cropping systems during both the years. Infection/infestation of diseases and insect pests in rice remained high when summer rice followed wet rice during both the years. Cropping systems having both rice crops (dry and wet) in quick succession were not ecologically viable in subtropical climate because of the risk of several insect pests and diseases (Gangwar et al., 1986; Ghosh \& Dasgupta, 1995).

After balancing the crop removal, rice-based cropping system showed lower total $\mathrm{N}$ status than expected and ultimately led to an overall loss of total $\mathrm{N}$ in spite of recommended dose for all crops (Table 3). However, the loss varied from $26 \mathrm{~kg} \mathrm{~N}^{-1}$ under rice-rice cropping system to $128 \mathrm{~kg} \mathrm{~N} \mathrm{ha}^{-1}$ under ricerapeseed-rice cropping system. The balance should be 
Table 1 Crop productivity, rice equivalent yield and economics of different cropping systems in Nadia district of West Bengal, India

\begin{tabular}{|c|c|c|c|c|c|c|c|c|c|c|c|c|c|c|c|c|}
\hline \multirow{3}{*}{$\begin{array}{c}\text { Cropping } \\
\text { system }\end{array}$} & \multicolumn{6}{|c|}{ Yield of crops $\left(\mathrm{t} \mathrm{ha}^{-1}\right)$} & \multirow{2}{*}{\multicolumn{2}{|c|}{$\begin{array}{l}\text { Rice equivalent } \\
\text { yield }\left(\mathbf{t} \mathbf{h a}^{-1}\right)\end{array}$}} & \multirow{2}{*}{\multicolumn{2}{|c|}{$\begin{array}{l}\text { Cost of cultivation } \\
\qquad\left(\mathrm{US} \$ \mathrm{ha}^{-1} \text { ) }\right.\end{array}$}} & \multirow{2}{*}{\multicolumn{2}{|c|}{$\begin{array}{l}\text { Gross return } \\
\left(\text { US \$ ha }{ }^{-1}\right)\end{array}$}} & \multirow{2}{*}{\multicolumn{2}{|c|}{$\begin{array}{l}\text { Net return } \\
\left(\mathbf{U S} \$ \mathbf{h a}^{-\mathbf{1}}\right)\end{array}$}} & \multirow{2}{*}{\multicolumn{2}{|c|}{$\begin{array}{c}\text { Return/dollar } \\
\text { Invested }\end{array}$}} \\
\hline & \multicolumn{3}{|c|}{ 2012-2013 } & \multicolumn{3}{|c|}{ 2013-2014 } & & & & & & & & & & \\
\hline & Rainy & Winter & Summer & Rainy & Winter & Summer & $12-13$ & $13-14$ & $12-13$ & 13-14 & $12-13$ & 13-14 & $12-13$ & 13-14 & $12-13$ & $13-14$ \\
\hline $\mathrm{R}-\mathrm{R}$ & $4.43^{\mathrm{a}}$ & - & $5.00^{\mathrm{ab}}$ & $3.26^{\mathrm{b}}$ & - & $4.07^{\mathrm{b}}$ & $9.43^{\mathrm{e}}$ & $7.33^{\mathrm{d}}$ & $697^{\mathrm{d}}$ & $648^{e}$ & $1178^{f}$ & $975^{f}$ & $481^{\mathrm{ef}}$ & $327^{\mathrm{e}}$ & $0.69^{\mathrm{de}}$ & $0.50^{\mathrm{de}}$ \\
\hline $\mathrm{R}-\mathrm{W}$ & $4.41^{\mathrm{a}}$ & $2.38^{\mathrm{c}}$ & - & $3.20^{\mathrm{b}}$ & $3.07^{\mathrm{c}}$ & - & $7.30^{\mathrm{f}}$ & $7.18^{\mathrm{d}}$ & $561^{\mathrm{e}}$ & $554^{\mathrm{f}}$ & $933^{g}$ & $955^{\mathrm{f}}$ & $373^{\mathrm{f}}$ & $400^{\mathrm{e}}$ & $0.60^{\mathrm{e}}$ & $0.72^{\text {cd }}$ \\
\hline R-P-R & $4.34^{\mathrm{a}}$ & $25.05^{\mathrm{b}}$ & $5.58^{\mathrm{a}}$ & $3.86^{\mathrm{a}}$ & $26.38^{\mathrm{b}}$ & $4.78^{\mathrm{a}}$ & $22.02^{\mathrm{b}}$ & $21.44^{\mathrm{b}}$ & $1258^{\mathrm{a}}$ & $1232^{\mathrm{a}}$ & $2523^{b}$ & $2498^{b}$ & $1265^{b}$ & $1267^{\mathrm{b}}$ & $1.01^{\mathrm{b}}$ & $1.03^{\mathrm{b}}$ \\
\hline R-P-S & $4.47^{\mathrm{a}}$ & $27.43^{\mathrm{ab}}$ & $0.88^{\mathrm{c}}$ & $3.94^{\mathrm{a}}$ & $25.81^{\mathrm{b}}$ & $1.10^{\mathrm{c}}$ & $19.93^{\mathrm{c}}$ & $19.22^{\mathrm{b}}$ & $980^{\mathrm{b}}$ & $965^{\text {bc }}$ & $2210^{c}$ & $2195^{c}$ & $1230^{\mathrm{b}}$ & $1230^{\mathrm{b}}$ & $1.25^{\mathrm{a}}$ & $1.27^{\mathrm{a}}$ \\
\hline R-Re-R & $4.41^{\mathrm{a}}$ & $0.83^{\mathrm{c}}$ & $4.77^{\mathrm{b}}$ & $2.94^{\mathrm{b}}$ & $1.70^{\mathrm{c}}$ & $3.91^{\mathrm{b}}$ & $10.73^{\mathrm{e}}$ & $10.62^{\mathrm{d}}$ & $864^{\mathrm{c}}$ & $845^{\mathrm{d}}$ & $1367^{\mathrm{e}}$ & $1390^{\mathrm{d}}$ & $503^{\mathrm{de}}$ & $545^{\mathrm{d}}$ & $0.58^{\mathrm{e}}$ & $0.64^{\mathrm{de}}$ \\
\hline $\mathrm{J}-\mathrm{R}-\mathrm{R}$ & $3.45^{\mathrm{b}}$ & $3.27^{\mathrm{c}}$ & $5.19^{\mathrm{ab}}$ & $2.39^{\mathrm{c}}$ & $2.49^{\mathrm{c}}$ & $4.37^{\mathrm{ab}}$ & $13.96^{\mathrm{d}}$ & $10.68^{d}$ & $959^{\mathrm{b}}$ & $939^{\mathrm{b}}$ & $1789^{d}$ & $1388^{d}$ & $830^{\mathrm{c}}$ & $450^{d}$ & $0.86^{\text {bcd }}$ & $0.48^{\mathrm{e}}$ \\
\hline $\mathrm{J}-\mathrm{W}$ & $3.45^{\mathrm{b}}$ & $3.13^{\mathrm{c}}$ & - & $2.47^{\mathrm{c}}$ & $3.85^{\mathrm{c}}$ & - & $9.83^{\mathrm{e}}$ & $9.34^{\mathrm{d}}$ & $644^{\mathrm{d}}$ & $633^{\mathrm{e}}$ & $1232^{\mathrm{e}}$ & $1180^{\mathrm{e}}$ & $607^{\mathrm{d}}$ & $546^{\mathrm{d}}$ & $0.94^{\mathrm{bc}}$ & $0.86^{\mathrm{bc}}$ \\
\hline J-P-R & $3.47^{\mathrm{b}}$ & $31.55^{\mathrm{a}}$ & $5.70^{\mathrm{a}}$ & $3.17^{\mathrm{a}}$ & $29.51^{\mathrm{a}}$ & $4.88^{\mathrm{a}}$ & $27.36^{\mathrm{a}}$ & $23.70^{\mathrm{a}}$ & $1331^{\mathrm{a}}$ & $1298^{\mathrm{a}}$ & $3079^{a}$ & $2700^{\mathrm{a}}$ & $1748^{a}$ & $1402^{\mathrm{a}}$ & $1.31^{\mathrm{a}}$ & $1.08^{\mathrm{ab}}$ \\
\hline J-Re-R & $3.42^{\mathrm{b}}$ & $1.06^{\mathrm{c}}$ & $4.80^{\mathrm{ab}}$ & $2.21^{\mathrm{c}}$ & $1.98^{\mathrm{c}}$ & $4.06^{\mathrm{b}}$ & $12.91^{\mathrm{d}}$ & $12.36^{\mathrm{c}}$ & $929^{\mathrm{b}}$ & $906^{\mathrm{c}}$ & $1644^{\mathrm{d}}$ & $1559^{d}$ & $715^{\text {cd }}$ & $653^{\mathrm{c}}$ & $0.77^{\text {cde }}$ & $0.72^{\text {cd }}$ \\
\hline $\operatorname{SEM}( \pm)$ & 0.19 & 0.87 & 0.27 & 0.14 & 0.88 & 0.26 & 0.55 & 0.49 & 25 & 26 & 66 & 66 & 41 & 39 & 0.08 & 0.07 \\
\hline $\operatorname{LSD}(\mathrm{P}=0.05)$ & 0.61 & 2.55 & 0.83 & 0.42 & 2.67 & 0.76 & 1.64 & 1.46 & 72 & 76 & 198 & 199 & 120 & 109 & 0.23 & 0.22 \\
\hline
\end{tabular}

$\mathrm{R}$, rice; W, wheat; P, potato; S, sesame; Re, rapeseed; J, jute

Table 2: Incidence of key insect pests and diseases of different crops under different cropping systems in Nadia district of West Bengal, India

\begin{tabular}{|c|c|c|c|c|c|c|c|c|c|c|c|c|c|c|c|c|c|c|}
\hline \multirow{4}{*}{$\begin{array}{c}\text { Cropping } \\
\text { system }\end{array}$} & \multirow{2}{*}{\multicolumn{6}{|c|}{$\begin{array}{c}\text { Pest incidence in jute } \\
\text { Yellow mite (\% infected plant) }\end{array}$}} & \multicolumn{6}{|c|}{ Pest incidence in wet season rice } & \multicolumn{6}{|c|}{ Pest incidence in dry season rice } \\
\hline & & & & & & & \multirow{2}{*}{\multicolumn{2}{|c|}{$\begin{array}{l}\text { Yellow stem borer } \\
\text { at } 60 \mathrm{DAT}\end{array}$}} & \multirow{2}{*}{\multicolumn{2}{|c|}{$\begin{array}{c}\text { Rice bug at } \\
\text { harvest }\end{array}$}} & \multirow{2}{*}{\multicolumn{2}{|c|}{$\begin{array}{c}\text { Sheath blight at } 60 \\
\text { DAT }\end{array}$}} & \multirow{2}{*}{\multicolumn{2}{|c|}{$\begin{array}{c}\text { Yellow stem borer at } \\
60 \mathrm{DAT}\end{array}$}} & \multirow{2}{*}{\multicolumn{2}{|c|}{$\begin{array}{c}\text { Rice bug at } \\
\text { harvest }\end{array}$}} & \multirow{2}{*}{\multicolumn{2}{|c|}{$\begin{array}{c}\text { Sheath blight at } \\
60 \text { DAT }\end{array}$}} \\
\hline & \multicolumn{2}{|c|}{ 30DAS } & \multicolumn{2}{|c|}{ 60DAS } & \multicolumn{2}{|c|}{ 90DAS } & & & & & & & & & & & & \\
\hline & $\frac{2}{\unlhd}$ & $\frac{\Delta}{m}$ & $\frac{m}{\beth}$ & $\frac{\Delta}{n}$ & $\frac{m}{\beth}$ & $\frac{\Delta}{m}$ & $\frac{m}{\beth}$ & $\frac{\Delta}{m}$ & $\frac{m}{\unlhd}$ & $\frac{\Delta}{m}$ & $\frac{m}{\beth}$ & $\frac{\Delta}{n}$ & $\frac{2}{\unlhd}$ & $\frac{\Delta}{n}$ & $\frac{m}{\beth}$ & $\frac{\Delta}{m}$ & $\frac{m}{\beth}$ & $\frac{\Delta}{m}$ \\
\hline $\mathrm{R}-\mathrm{R}$ & & & & & & & 4.66 & $10.56^{\mathrm{a}}$ & 14.30 & $16.70^{\mathrm{a}}$ & $6.10^{\mathrm{a}}$ & $5.23^{\mathrm{b}}$ & $5.02^{\mathrm{ab}}$ & 7.63 & $8.22^{\mathrm{ab}}$ & $1.30^{\mathrm{b}}$ & $2.20^{\mathrm{ab}}$ & $1.30^{\mathrm{c}}$ \\
\hline $\mathrm{R}-\mathrm{W}$ & & & & & & & 3.23 & $5.21^{\mathrm{b}}$ & 16.40 & $11.60^{\mathrm{b}}$ & $4.84^{\mathrm{b}}$ & $3.15^{\mathrm{c}}$ & & & & & & \\
\hline R-P-R & & & & & & & 3.02 & $9.73^{\mathrm{a}}$ & 17.60 & $15.50^{\mathrm{a}}$ & $6.03^{\mathrm{a}}$ & $5.30^{\mathrm{b}}$ & $4.80^{\mathrm{ab}}$ & 8.24 & $9.92^{\mathrm{a}}$ & $1.10^{\mathrm{b}}$ & $0.30^{\mathrm{c}}$ & $1.10^{\mathrm{d}}$ \\
\hline R-P-S & & & & & & & 4.63 & $6.12^{\mathrm{b}}$ & 19.10 & $11.60^{\mathrm{b}}$ & $3.22^{\mathrm{c}}$ & $3.20^{\mathrm{c}}$ & & & & & & \\
\hline R-Re-R & & & & & & & 3.66 & $9.77^{\mathrm{a}}$ & 15.10 & $17.90^{\mathrm{a}}$ & $6.23^{\mathrm{a}}$ & $6.30^{\mathrm{a}}$ & $5.39^{\mathrm{a}}$ & 8.28 & $7.70^{\mathrm{b}}$ & $2.40^{\mathrm{a}}$ & $1.40^{\mathrm{b}}$ & $2.40^{\mathrm{a}}$ \\
\hline J-R-R & $3.02^{b}$ & $4.22^{\mathrm{b}}$ & 7.89 & 3.21 & $1.01^{\mathrm{b}}$ & $0.92^{\mathrm{b}}$ & & & & & & & $4.32^{\mathrm{b}}$ & 7.74 & $2.32^{\mathrm{d}}$ & $1.20^{\mathrm{b}}$ & $2.70^{\mathrm{a}}$ & $1.20^{\mathrm{cd}}$ \\
\hline $\mathrm{J}-\mathrm{W}$ & $2.51^{\mathrm{b}}$ & $3.61^{\mathrm{b}}$ & 6.82 & 2.71 & $1.82^{\mathrm{a}}$ & $0.69^{b}$ & & & & & & & & & & & & \\
\hline J-P-R & $4.32^{\mathrm{a}}$ & $8.99^{\mathrm{a}}$ & 8.08 & 2.19 & $1.83^{\mathrm{a}}$ & $1.86^{\mathrm{a}}$ & & & & & & & $4.11^{\mathrm{b}}$ & 7.62 & $4.56^{\mathrm{c}}$ & $2.10^{\mathrm{a}}$ & $1.22^{\mathrm{b}}$ & $2.10^{\mathrm{b}}$ \\
\hline J-Re-R & $3.22^{b}$ & $6.22^{\mathrm{ab}}$ & 5.94 & 2.18 & $0.62^{\mathrm{b}}$ & $0.97^{b}$ & & & & & & & $4.33^{\mathrm{b}}$ & 8.47 & $3.89^{\text {cd }}$ & $0.20^{\mathrm{c}}$ & $1.33^{\mathrm{b}}$ & $0.20^{\mathrm{e}}$ \\
\hline $\operatorname{SEM}( \pm)$ & 0.29 & 1.54 & 0.96 & 0.15 & 0.13 & 0.21 & 0.41 & 1.08 & 2.01 & 1.57 & 0.38 & 0.25 & 0.32 & 0.97 & 0.88 & 0.10 & 0.34 & 0.06 \\
\hline $\operatorname{LSD}(\mathrm{P}=0.05)$ & 0.83 & 3.72 & NS & NS & 0.40 & 0.62 & NS & 3.25 & NS & 4.79 & 1.12 & 0.76 & 0.99 & NS & 2.15 & 0.31 & 1.03 & 0.19 \\
\hline
\end{tabular}

Journal of Experimental Biology and Agriculture Science

http://www.jebas.org 
restored with integrated nutrient management utilising both organic and inorganic sources. Jute-based cropping systems, on the other hand, ultimately recorded higher values of total $\mathrm{N}$ status than expected, enriching soil $\mathrm{N}$ status. Jute-potato-rice cropping system contributed to the highest concentration of $194.7 \mathrm{~kg} \mathrm{~N} \mathrm{ha}^{-1}$. Jute, potato and wet rice resulted in increase soil nitrogen. Sadanandan \& Mahapatra (1973b) opined that jute checked nitrogen loss under rice-jute-rice and groundnut-jute-rice cropping systems to some extent. Nitrogen status decreased after wheat, sesame rapeseed and dry rice. Timsina et al. (2001) reported loss of total nitrogen under rice-wheat in Bangladesh. Kundu \& Samui (2000) also reported reduction in total nitrogen from $0.057 \%$ to $0.050 \%$ after ten years of rice-wheat in Kalyani (West Bengal).

Similarly, all the rice-based cropping systems except rice-rice recorded lower available $\mathrm{P}$ values than expected after balancing the crop removal and resulted in the overall loss of available $\mathrm{P}$, ranging from $14.4 \mathrm{~kg} \mathrm{ha}^{-1}$ available $\mathrm{P}$ in rice-wheat to $30 \mathrm{~kg} \mathrm{ha}^{-1}$ in rice-potato-rice system (Table 3). Rice-rice cropping system, on the contrary, added $5.5 \mathrm{~kg}$ available $\mathrm{P} \mathrm{ha}^{-1}$ into the soil system. Jute-based cropping systems except jute-potato-rice recorded negative values of available $\mathrm{P}$ due to higher uptake of $\mathrm{P}$ by jute and cereals. But all these systems showed higher values of available $P$ in soil than the expected values resulting in gain of available $P$ ranged from $20.6 \mathrm{~kg} \mathrm{ha}^{-1}$ in jute-potato - rice to $44.4 \mathrm{~kg} \mathrm{ha}^{-1}$ in jute - rice - rice cropping system. Available phosphorus status increased after jute and decreased after rice. Inclusion of potato in a cropping system also increased available soil phosphorus. Sadanandan \& Mahapatra (1973a) reported that slight loss of available phosphorus status after two years of potato-rice-rice, rice-jute-rice and rice-rice systems at Cuttack, Orissa. But available phosphorus was more under rice-mustard-okra, rice-ricegreen manure and rice-wheat-jute cropping systems at Kalyani (West Bengal) (Anonymous, 2001). But Kundu \& Samui (2000) and Saha et al. (2000) reported an increase of available phosphorus status after ten years of rice-wheat cropping system.

Most of the cropping systems except rice-wheat, rice-potato-rice and rice-potato-sesame recorded negative values of available $\mathrm{K}$ after balancing the crop removal (Table 3). However, the available $\mathrm{K}$ status in soil after completion of two cropping cycles showed considerable higher values in potato-inclusive cropping systems. The gain in available $\mathrm{K}$ in soil was higher under jute-based cropping systems than that of rice based cropping systems due to both release of fixed $\mathrm{K}$ into exchangeable complex and due to the soil-nutrient sustainability of jute, as shown in Table 3. After wet rice, wheat, sesame, dry rice and rapeseed available potassium decreased whereas, after potato and jute, available potassium built up in soil. Decline in available status under R-W, R-R, R-Re-R and J-Re-R might be due to removal of potassium rich straw under intensive cropping. Dobermann et al. (1998) also reported the decrease in $\mathrm{K}$ status in intensive irrigated rice-based cropping system in Asia. Increase in available potassium in soil in the cropping sequences having potato and jute as a component crop and decrease in available potassium content in rice-mustard-okra, rice-rice and rice-wheat-jute cropping systems were also noticed under AICRP on Cropping System at Kalyani (Anonymous, 2001).

\subsection{Energetics}

Total energy input in different cropping systems ranged from 23.2 GJ ha ${ }^{-1}$ in jute - wheat to $63.9 \mathrm{GJ} \mathrm{ha}^{-1}$ in jute - potato - rice cropping system (Table 4). Energy use was obviously higher in triple cropping systems as compared to double cropping systems. Triple cropping systems also recorded higher energy output through both economic and biological products than those from double cropping systems. Energy production was at its highest with jute-potato-rice but the lowest in rice-wheat system. The result of low energy productivity in rice-wheat was in agreement with the findings of Subbian et al. (1995) and Parihar et al. (1999). Potato cultivation is associated with higher requirement of inputs in the form of seed tuber, fertilizer, plant protection chemicals and irrigation water. Hence potato containing system reduced energy productivity inspite of high energy output. Jute on the other hand requires low energy for its cultivation and the highest use efficiency of cropping systems tested was jute-wheat followed by jute - rapeseed - rice and jute - rice -rice. Jute-based cropping systems were greater energy producers than those of rice-based cropping systems. As regards energy productivity, jute - potato rice recorded the highest yield per unit energy used $\left(690 \mathrm{~g} \mathrm{MJ}^{-1}\right)$ followed by rice - potato - rice $\left(561 \mathrm{~g} \mathrm{MJ}^{-1}\right)$ and rice - potato sesame $\left(478 \mathrm{~g} \mathrm{MJ}^{-1}\right)$ and showed superiority in energy productivity over all other cropping systems. This was mainly due to very high yield of potato. Productivity of rapeseed was lower than the crops tested and systems with rapeseed e.g. rice - rapeseed - rice and jute - rapeseed - rice resulted the lowest energy productivity (170 $\mathrm{g} \mathrm{MJ}^{-1}$ ). Energy requirement for rice production was more than that for jute production irrespective of cropping system due to higher energy expenditure in rice on land preparation, nitrogen fertilisation and irrigation in spite of higher labour requirement for jute. Energy output of wet season rice and jute follows similar trend but jute was more energy efficient crop than rice because of lower energy requirement. Energy input for the rice cultivation under R-P-R and R-P-S was at the highest. Energy input for jute under J-P-R was also higher than that of any other jute-based cropping system. Potato inclusive cropping systems also required much higher energy than other systems due to higher yield of wet season crops and greater amount of energy required foresting and processing. Jute under J-P-R was the most efficient and rice under $\mathrm{R}-\mathrm{R}, \mathrm{R}-\mathrm{W}$ and $\mathrm{R}-\mathrm{Re}-\mathrm{R}$ were the least energy efficient. In winter, potato required higher energy than other crops and in summer, rice required much higher input of energy than sesame. Among the winter crops, potato was the highest energy producer with highest energy consumption resulting least energy efficiency. However, energy use efficiency of wheat was higher than potato because of lower energy requirement. However, rapeseed is lowest in energy use and production. All winter crops grown after jute recorded greater energy output than those following rice. Dry season rice required higher energy than summer sesame due to higher energy requirement in field operation, plant nutrient and irrigation. Energy 
Table 3: Nutrient balance in soil after two years completion of different cropping systems in Nadia district of West Bengal, India

\begin{tabular}{|c|c|c|c|c|c|c|c|c|c|c|c|c|c|c|c|c|c|c|}
\hline \multirow{2}{*}{$\begin{array}{c}\text { Cropping } \\
\text { system }\end{array}$} & \multicolumn{6}{|c|}{ Nitrogen balance sheet ( Total $\mathbf{N} \mathrm{kg} \mathrm{ha}^{-1}$ ) } & \multicolumn{6}{|c|}{ Phosphorus balance sheet (Available $\mathrm{P} \mathrm{kg} \mathrm{ha}^{-1}$ ) } & \multicolumn{6}{|c|}{ Potassium balance sheet (Available $\mathrm{K} \mathrm{kg} \mathrm{ha-1}$ ) } \\
\hline & Initial & Input & $\begin{array}{c}\text { Crop } \\
\text { removal }\end{array}$ & $\begin{array}{l}\text { Balance } \\
(1+2-3)\end{array}$ & $\begin{array}{l}\text { Final } \\
\text { status }\end{array}$ & $\begin{array}{r}\text { Gain/Loss } \\
(5-4)( \pm)\end{array}$ & Initial & Input & $\begin{array}{c}\text { Crop } \\
\text { removal }\end{array}$ & $\begin{array}{c}\text { Balance } \\
(1+2-3)\end{array}$ & $\begin{array}{l}\text { Final } \\
\text { status }\end{array}$ & $\begin{array}{r}\text { Gain/Loss } \\
(5-4)( \pm)\end{array}$ & Initial & Input & $\begin{array}{c}\text { Crop } \\
\text { removal }\end{array}$ & $\begin{array}{c}\text { Balance } \\
(1+2-3)\end{array}$ & $\begin{array}{l}\text { Final } \\
\text { status }\end{array}$ & $\begin{array}{r}\text { Gain/Loss } \\
(5-4)( \pm)\end{array}$ \\
\hline & (1) & (2) & (3) & (4) & (5) & (6) & (1) & (2) & (3) & (4) & (5) & (6) & (1) & (2) & (3) & (4) & (5) & (6) \\
\hline $\mathrm{R}-\mathrm{R}$ & 1012 & 320 & $338^{\mathrm{e}}$ & 994 & $968^{\mathrm{e}}$ & -26 & 24 & 71.1 & $77.0^{\mathrm{d}}$ & 18.1 & $23.6^{\mathrm{d}}$ & +5.5 & 140 & 133 & $322^{\mathrm{e}}$ & -48.8 & $119^{\mathrm{d}}$ & +168 \\
\hline $\mathrm{R}-\mathrm{W}$ & 1012 & 320 & $264^{\mathrm{f}}$ & 1068 & $946^{\text {ef }}$ & -122 & 24 & 71.1 & $57.3^{d}$ & 37.8 & $23.4^{\mathrm{d}}$ & -14.4 & 140 & 133 & $256^{\mathrm{f}}$ & 16.9 & $120^{\mathrm{d}}$ & +103 \\
\hline R-P-R & 1012 & 720 & $551^{\mathrm{b}}$ & 1180 & $1056^{\mathrm{cd}}$ & -124 & 24 & 160.0 & $117.8^{\mathrm{b}}$ & 66.2 & $40.6^{\mathrm{ab}}$ & -25.6 & 140 & 382 & $488^{b}$ & 33.6 & $155^{\mathrm{ab}}$ & +121 \\
\hline R-P-S & 1012 & 620 & $486^{\text {cd }}$ & 1146 & $1022^{d}$ & -124 & 24 & 137.8 & $92.1^{\mathrm{c}}$ & 69.7 & $39.2^{\mathrm{b}}$ & -30.5 & 140 & 340 & $382^{\mathrm{d}}$ & 98.0 & $150^{\mathrm{b}}$ & +52 \\
\hline R-Re-R & 1012 & 480 & $463^{d}$ & 1029 & $900^{\mathrm{f}}$ & -129 & 24 & 106.7 & $92.4^{\mathrm{c}}$ & 38.3 & 21.8 & -16.5 & 140 & 199 & $358^{\mathrm{d}}$ & -18.3 & 108 & +126 \\
\hline J-R-R & 1012 & 400 & $507^{\mathrm{c}}$ & 905 & $1078^{\mathrm{bc}}$ & +173 & 24 & 88.9 & $128.7^{b}$ & -15.8 & $28.6^{\mathrm{cd}}$ & +44.4 & 140 & 199 & $502^{b}$ & -163.0 & $132^{\mathrm{c}}$ & +295 \\
\hline $\mathrm{J}-\mathrm{W}$ & 1012 & 280 & $349^{\mathrm{e}}$ & 943 & $1120^{\mathrm{b}}$ & +177 & 24 & 62.9 & $91.6^{c}$ & -4.7 & $28.2^{\text {cd }}$ & +32.9 & 140 & 149 & $357^{d}$ & -67.7 & $140^{\mathrm{bc}}$ & +208 \\
\hline J-P-R & 1012 & 680 & $647^{\mathrm{a}}$ & 1045 & $1240^{\mathrm{a}}$ & +195 & 24 & 157.1 & $155.3^{\mathrm{a}}$ & 25.8 & $46.4^{\mathrm{a}}$ & +20.6 & 140 & 398 & $601^{\mathrm{a}}$ & -62.4 & $168^{\mathrm{a}}$ & +230 \\
\hline J-Re-R & 1012 & 440 & $552^{\mathrm{b}}$ & 900 & $1050^{\text {cd }}$ & +150 & 24 & 97.8 & $123.2^{b}$ & -1.4 & $25.8^{\text {cd }}$ & +27.2 & 140 & 216 & $446^{c}$ & -90.4 & $130^{c}$ & +220 \\
\hline $\operatorname{SEM}( \pm)$ & & & 14.4 & & 15.9 & & & & 5.8 & & 2.2 & & & & 11 & & 6 & \\
\hline $\operatorname{LSD}(\mathrm{P}=$ & .05) & & 43.0 & & 47.3 & & & & 17.5 & & 6.7 & & & & 33 & & 17 & \\
\hline
\end{tabular}

Table 4 Energetics of different cropping systems in Nadia district of West Bengal, India

\begin{tabular}{|c|c|c|c|c|c|c|c|c|c|c|c|c|}
\hline \multirow[t]{3}{*}{ Cropping system } & \multicolumn{2}{|c|}{$\begin{array}{l}\text { Energy input } \\
\left(\mathbf{G J} \mathbf{h a}^{-1}\right)\end{array}$} & \multicolumn{4}{|c|}{ Energy output (GJ ha' $\left.{ }^{-1}\right)$} & \multicolumn{4}{|c|}{$\begin{array}{c}\text { Energy use efficiency } \\
\text { (Output/input ratio) }\end{array}$} & \multicolumn{2}{|c|}{$\begin{array}{c}\text { Energy productivity } \\
\left(\mathrm{g} \mathrm{MJ}^{-1}\right)\end{array}$} \\
\hline & \multirow[b]{2}{*}{$12-13$} & \multirow[b]{2}{*}{$13-14$} & \multicolumn{2}{|c|}{ Economic } & \multicolumn{2}{|c|}{ Biological } & \multicolumn{2}{|c|}{ Economic } & \multicolumn{2}{|c|}{ Biological } & \multirow[b]{2}{*}{$12-13$} & \multirow[b]{2}{*}{$13-14$} \\
\hline & & & $12-13$ & $13-14$ & $12-13$ & $13-14$ & $12-13$ & 13-14 & $12-13$ & 13-14 & & \\
\hline $\mathrm{R}-\mathrm{R}$ & 33.8 & 33.0 & $138.6^{\mathrm{e}}$ & $109.2^{\mathrm{e}}$ & $273.7^{\mathrm{d}}$ & 251.0 & $4.09^{\mathrm{bc}}$ & $3.31^{\mathrm{d}}$ & $8.09^{\mathrm{cd}}$ & $7.61^{\mathrm{cd}}$ & $225^{\mathrm{c}}$ & $279^{\mathrm{c}}$ \\
\hline $\mathrm{R}-\mathrm{W}$ & 27.1 & 26.6 & $99.8^{\mathrm{f}}$ & $92.2^{\mathrm{e}}$ & $203.2^{\mathrm{e}}$ & 217.2 & $3.68^{\mathrm{cd}}$ & $3.46^{\mathrm{cd}}$ & $7.49^{\mathrm{de}}$ & $8.16^{\mathrm{bc}}$ & $190^{\mathrm{c}}$ & $201^{\mathrm{c}}$ \\
\hline R-P-R & 67.6 & 67.2 & $241.1^{\mathrm{b}}$ & $227.4^{\mathrm{b}}$ & $385.6^{\mathrm{b}}$ & 386.4 & $3.56^{\mathrm{d}}$ & $3.38^{\mathrm{cd}}$ & $5.70^{\mathrm{f}}$ & $5.75^{\mathrm{e}}$ & $563^{\mathrm{ab}}$ & $559^{\mathrm{ab}}$ \\
\hline R-P-S & 53.1 & 52.9 & $195.8^{\mathrm{c}}$ & $188.3^{\mathrm{c}}$ & $292.3^{\mathrm{d}}$ & 328.6 & $2.82^{\mathrm{e}}$ & $3.56^{\mathrm{c}}$ & $5.50^{\mathrm{f}}$ & $6.21^{\mathrm{e}}$ & $466^{\mathrm{b}}$ & $490^{\mathrm{b}}$ \\
\hline R-Re-R & 43.8 & 43.5 & $152.4^{\text {de }}$ & $135.6^{\mathrm{d}}$ & $328.0^{\mathrm{c}}$ & 320.6 & $3.46^{\mathrm{d}}$ & $3.12^{\mathrm{e}}$ & $6.09^{\text {ef }}$ & $7.20^{\mathrm{d}}$ & $156^{\mathrm{c}}$ & $184^{\mathrm{c}}$ \\
\hline J-R-R & 42.7 & 41.3 & $186.1^{\mathrm{c}}$ & $143.6^{\mathrm{d}}$ & $397.7^{\mathrm{b}}$ & 328.4 & $4.36^{\mathrm{ab}}$ & $3.48^{\mathrm{cd}}$ & $9.31^{\mathrm{bc}}$ & $7.96^{\mathrm{bc}}$ & $185^{\mathrm{c}}$ & $231^{\mathrm{c}}$ \\
\hline $\mathrm{J}-\mathrm{W}$ & 23.5 & 22.9 & $107.8^{\mathrm{f}}$ & $100.8^{\mathrm{e}}$ & $270.9^{d}$ & 244.3 & $4.59^{\mathrm{a}}$ & $4.46^{\mathrm{ad}}$ & $11.54^{\mathrm{a}}$ & $10.68^{\mathrm{a}}$ & $210^{c}$ & $210^{\mathrm{c}}$ \\
\hline J-P-R & 64.2 & 63.6 & $265.9^{\mathrm{a}}$ & $240.8^{\mathrm{a}}$ & $464.1^{\mathrm{a}}$ & 403.7 & $4.14^{\mathrm{ab}}$ & $3.78^{\mathrm{b}}$ & $7.23^{\mathrm{d}}$ & $6.34^{\mathrm{e}}$ & $668^{a}$ & $713^{a}$ \\
\hline J-Re-R & 40.3 & 39.9 & $153.8^{\mathrm{d}}$ & $140.3^{d}$ & $388.6^{\mathrm{b}}$ & 339.7 & $3.82^{\text {cd }}$ & $3.52^{\mathrm{c}}$ & $9.65^{\mathrm{b}}$ & $8.51^{\mathrm{b}}$ & $161^{\mathrm{c}}$ & $178^{\mathrm{c}}$ \\
\hline $\operatorname{SEM}( \pm)$ & & & 4.5 & 3.2 & 14.0 & 13.6 & 0.17 & 0.06 & 0.50 & 0.21 & 42 & 35 \\
\hline $\operatorname{LSD}(P=0.05)$ & & & 14.7 & 12.5 & 42.1 & 40.6 & 0.50 & 0.18 & 1.47 & 0.61 & 125 & 117 \\
\hline
\end{tabular}

Journal of Experimental Biology and Agriculture Science

http://www.jebas.org 
output was higher in rice than in sesame but use efficiency of energy was higher in sesame than rice. Among various systems, JW was the most energy efficient while R-Re-R was the least efficient in terms of economic yield.

\section{Conclusion}

Cropping systems involving potato are highly productive in terms of yield, economics, improvement or maintenance of soil fertility. Jute in system improved soil fertility in terms of total nitrogen and available $\mathrm{P}$ and but available $\mathrm{K}$ status decline. Negative $\mathrm{N}$ balance was recorded with rice based systems. But continuous growing of rice both as kharif and boro season may not be ecologically sustainable due to possible biotic threat and possibility of acute nutrient deficiency owing to continuous mining of similar nutrients. Economically jute - potato - rice, rice - potato - rice and rice - potato - sesame are suitable for large and medium farmers for higher return. But these systems were higher energy productive at the cost of higher consumption resulting lower energy productivity. Jute - wheat and jute - rapeseed - rice can be considered suitable for small and marginal farmers because of their moderate cost of production and net return with better energy use efficiency. The present research addresses the problems continuous growing of rice-rice or rice wheat cropping system. Alternate systems, through crop diversification involving potato and jute were tested on the basis sustainability parameters to find out possible recommendations for the resource poor and resource rich farmers. This study has also emphasized the necessity of further detailed study on nutrient balance, pest dynamics, energy efficiency of existing systems and new systems for long term sustainability.

\section{References}

Anonymous (2001) Annual report 2000-2001. AICPR on cropping system research, BCKVV, Kalyani, West Bengal.

Bhandari AL, Ladha JK, Pathak H, Padre AT, Dawe D, Gupta RK (2002) Yield and soil nutrient changes in a long-term rice-wheat rotation in India. Soil Science Society of America Journal 60: 162170. doi:10.2136/sssaj2002.1620.

Biswas B, Ghosh DC, Dasgupta MK, Trivedi N, Timsina J, Dobermann A (2006) Integrated assessment of cropping systems in the Eastern Indo-Gangetic plain. Field Crops Research 99: 3547.

Dobermann A, Cassman KG, Mamaril CP, Shuhy JE (1998) Management of phosphorus, potassium and sulphur in intensive, irrigated lowland rice. Field Crops Research 56: 113-138.

Gangwar SK, Chakraborty S, Dasgupta MK, Huda AKS (1986) Modeling yield loss in indica rice in farmers' fields due to multiple pests. Agriculture Ecosystems and Environment 17:165-171.
Ghosh M, Dasgupta MK (1995) Potentiality of natural insect pest population and its effect on rice yield in West Bengal, India. Proceeding of National Symposium on Sustainable Agriculture in Sub-humid Zone, Institute of Agriculture, Visva-Bharati, Sriniketan, March: 3-5, 1995, Pp. 331-333.

Gomez KA, Gomez AA (1984) Statistical Procedures for Agricultural Research. $2^{\text {nd }}$ Edn. New York: Wiley.

Kundu AL (1989) Intensive cropping system in terai zone of West Bengal. Proceedings of National seminar on Agroecosystems Management, Sriniketan, February 18-21, 1989, Pp. 161-165.

Kundu AL, Samui RC (1998) Studies on different crop sequences in farmers' field. International seminar on jute and allied fibre: Changing global scenario, 5-6 February, 1998, Kolkata, India.

Kundu BC, Samui RC (2000) Long-term soil fertility experiment in Rice-Wheat Cropping System in West Bengal. In: Abrol IP, Bronson KF, Duxbury JM, Gupta RK (Eds.), Long-term Soil Fertility Experiments in Rice-wheat cropping Systems. Rice-Wheat consortium Paper Series 6. Rice-Wheat Consortium for the IndoGangetic Plains, New Dehli, pp 63-67.

Mandal AK, Roy AB, Pal H (1981) Fertilizer use in jute based cropping system in different Agro-climatic zones. Fertilizer News, September, 45-50.

Mittal VK, Mittal JP, Dhawan KC (1985) Research Digest on energy requirements in agricultural sector. In: Energy Requirements Scheme Report, 1985. Indian council of Agricultural Research, New Delhi.

Mukhopadhyaya SK, Ray D (2000) Potato-based crop rotations in West Bengal. Environment and Ecology18: 793-797.

Parihar SS, Pandey D, Shukla RK, Verma VK, Chaure NK, Choudhar KK, Pandya KS (1999) Energetics, yield, water use and economics of rice based cropping system. Indian Journal of Agronomy 44 :205-209.

Roy SKB, Walker TS, Khatana VS, Saha MK, Verma VS, Kadian MS, Haverkort AJ, Bowen WT (1999) Intensification of potatoes in rice-based cropping systems: a rapid rural appraisal in West Bengal. Workshop paper Series. International Potato Centre No. 1999-1.

Sadanandan N, Mahapatra IC (1973a) Studies on multiple cropping - Balance sheet of total and available phosphorus in various cropping patterns. Indian Journal of Agronomy 18:459463.

Sadanandan N, Mahapatra IC (1973b) Studies on multiple cropping - Balance sheet of nitrogen in various cropping patterns. Indian Journal of Agronomy 18: 323-327. 
Saha MN, Saha A, Mandal BC, Roy PK (2000) Effect of long-term Jute-Rice-Wheat Cropping System on Crop Yield and Soil Fertility. In: Abrol IP, Bronson KF, Duxbury JM, Gupta RK (Eds.), Long-term Soil Fertility Experiments in Rice-wheat cropping Systems. Rice-Wheat consortium Paper Series 6. RiceWheat Consortium for the Indo-Gangetic Plains, New Dehli, pp 94-104.

Sarkar A (1997) Energy use patterns in sub-tropical rice-wheat cropping under short-term application of crop residue and fertilizer. Agriculture, Ecosystems \& Environment 61: 59-67. DOI: https://doi.org/10.1016/S0167-8809(96)01069-9.

SenGupta PK (2001) Monograph on West Bengal. Directorate of Agriculture, Government of West Bengal, Kolkata, India.
Subbian P, Gopalsundaran P, Palaniappan SP (1995) Energetics and water use efficiency of intensive cropping system. Indian Journal of Agronomy 40:398-401

Timsina J, Connor DJ (2001) Productivity and management of ricewheat cropping systems: issues and challenges. Field Crops Research 69: 93-132.

Timsina J, Singh U, Badaruddin M, Meisner C, Amin MR (2001) Cultivar, nitrogen, and water effects on productivity, and nitrogen-use efficiency and balance for rice-wheat sequences of Bangladesh. Field Crops Research 72: 143-161.

Zaman A, Choudhuri SK (2001) Water use, productivity and production economics of different crop sequences under upland rainfed condition. Indian Agriculturist 45 : 103-108. 